\title{
Analisis Metode al-Qiraah al-Jahriyyah dalam Meningkatkan Keterampilan Membaca Teks Berbahasa Arab
}

\author{
1. Muhammad Zaky Sya'bani ${ }^{2 .}$ Khairil Anwar \\ 1. STIT Darul Fattah Bandar Lampung ${ }^{2}$ STIT Darul Fattah Bandar Lampung \\ 1. mzaky@darulfattah.ac.id ${ }^{2 .}$ khairila@darulfattah.ac.id
}

\begin{abstract}
Many of the problems in Arabic language learning are found by students, for those who do not have Islamic educational background. SMAIT Insantama is one example of a school that has students with a diversity of previous educational background. Many students studying in the school have minimal knowledge of Arabic language, for students who have difficulty reading Arabic texts. The teachers at SMAIT Insantama tried to alleviate the problem by implementing the Al-Qiraah al-Jahriyah method as a solution to the problem. This research aims to describe the problem in SMAIT Insantama and the solutions given so that it can solve the problems that exist. And the method used is a descriptive analysis, a study with an investigation approach to upload the problem thoroughly. While the results are found with the application of al-Qiraah al-Jahriyah method students are more active in Arabic language learning and more daring to pronounce the vocabulary read. And after several meetings by implementing the method al-Qiraah al-Jahriyah students who previously did not have the mental to read the Arabic text in front of the other students is now more daring and even the degree of guilt was reduced. This is a challenge with students ' learning outcomes in their cycle tests with an increase of $9.37 \%$ or 75.25 in the 1 st, 84.38 cycles of the 2 nd and the 92.29 in the 3 rd cycle. Thus, al-Qiraah al-Jahriyah method is very suitable to alleviate students ' problems in reading Arabic text.
\end{abstract}

Keywords : Analysis, Al-Qiraah al-Jahriyyah, Arabic Language

\begin{abstract}
ABSTRAK
Berbagai permasalah dalam pembelajaran bahasa Arab banyak didapati oleh siswa, dengan berbagai latar belakang pendidikan terkhusus pendidikan bernuansa islami. SMAIT Insantama merupakan salah satu contoh sekolah yang memiliki siswa dengan keberagaman latar belakang pendidikan sebelumnya. Banyak siswa yang belajar di sekolah tersebut akantetapi minim akan pengetahuan bahasa Arab, terlebih lagi para siswa kesulitan dalam membaca teks-teks berbahasa Arab. Para guru di SMAIT Insantama mencoba mengentaskan permasalahan tersebut dengan menerapkan metode al-Qiraah al-Jahriyah sebagai solusi atas permasalahan tersebut. penelitian ini bertujuan untuk mendeskripsikan permasalahan di SMIT Insantama serta solusi yang diberikan sehingga dapat menentaskan permasalahan yang ada. Adapun metode yang digunakan adalah analisis deskriptif, sebuah penelitian dengan pendekatan investigasi guna mengunggkap permasalahan dengan tuntas. Hasil yang didapati adalah dengan penerapan metode al-Qiraah al-Jahriyah siswa lebih aktif dalam pembelajaran bahasa Arab dan lebih berani untuk mengucapkan kosakata yang dibaca. Dan setelah beberapa pertemuan dengan menerapkan metode al-Qiraah al-Jahriyah siswa yang sebelumnya tidak memiliki mental untuk membacakan teks berbahasa Arab di depan siswa lainnya kini lebih berani dan bahkan tingkat kesalahannya pun berkurang. Hal ini sebangding dengan hasil belajar siswa pada uji siklusnya dengan peningkatan $9,37 \%$ atau 75,25 pada siklus ke-1, 84,38 pada siklus ke-2 dan 92,29 pada siklus ke-3. Dengan demikian metode al-
\end{abstract}


Qiraah al-Jahriyah sangat cocok untuk menentaskan permasalahan siswa dalam membaca teks berbahasa Arab.

\section{Kata Kunci : Analisis, al-Qiraah al-Jahriyyah, Bahasa Arab}

\section{PENDAHULUAN}

Bahasa Arab menjadi bahasa resmi di semua negara Arab. Ia menjadi bahasa komunikasi dan juga bahasa pengantar dalam pembelajaran di sekolah-sekolah, lembagalembaga pendidikan, dan di perguruan tinggi. Bahasa Arab mampu menghilangkan kebodohan dan memotivasi untuk berkembang dan bangkit.

Bahasa Arab adalah bahasa orang Arab dan Islam. Bahasa Arab merupakan bahasa yang digunakan sebagai alat komunikasi internasional dan memiliki peran yang sangat penting dalam memberikan khazanah keilmuan baik dari satu generasi ke generasi berikutnya (Abdurrochman, 2016:5).

Bahasa Arab sebagai salah satu bahasa asing di Indonesia. Saat ini bahasa Arab menduduki peringkat ke-2 setelah bahasa Inggris dilihat dari pengguna. Akan tetapi, sebenarnya bahasa Arab lebih dahulu dikenal orang Indonesia karena bahasa Arab masuk ke Nusantara bersamaan dengan masuknya agama Islam di wilayah tersebut (Syamsuddin Asyrofi, 2016:148).

Bahasa Arab di Indonesia sudah menjadi mata pelajaran dalam kegiatan belajar mengajar bagi pesantren, madrasah, sekolah Islam terpadu maupun di sekolah umum yang menjadikan bahasa Arab dalam muatan pelajarannya. Pembelajaran bahasa Arab juga telah memiliki Standar Kompetensi dan Standar Isi. Hal ini tercantum dalam Peraturan Menteri Agama RI nomor 2 tahun 2008 tentang Standar Kompetensi Lulusan dan Standar Isi Pendidikan Agama Islam dan Bahasa Arab.

Bahasa Arab juga diajarkan untuk memahami Al-Qur'ān dan Hadist. Bahasa Arab mulai dituturkan diantara murid-murid pondok pesantren dan siswa-siswi yang tinggal di asrama-asrama sekolah. Sudah lama bangsa Indonesia tidak menyadari betapa pentingnya bahasa Arab sehingga sampai saat ini belum berani menetapkan bahasa Arab sebagai salah satu mata pelajaran yang diujikan secara nasional. Jika saja bahasa Arab diujikan secara nasional, maka sudah pasti siswa akan termotivasi untuk mempelajari dan menguasai bahasa tersebut.

Keberagaman latar belakang pendidikan siswa juga menjadi salah satu masalah yang dihadapi dalam pengajaran bahasa Arab di Madrasah-madrasah Aliyah misalnya, 
ada siswa yang berasal dari Madrasah Tsanawiyah dan Sekolah Dasar. Perbedaan latar belakang pendidikan ini pada gilirannya menyebabkan pengetahuan siswa akan Bahasa Arab sangat heterogen. Diantara para siswa sudah ada yang mampu membaca huruf Arab, dan ada juga yang sama sekali tidak mengenal huruf Arab. Sedangkan kemampuan mengenal huruf Arab merupakan modal awal untuk mempelajari bahasa Arab lebih lanjut.

Berdasarkan kondisi kemampuan siswa yang seperti ini, maka sangat mungkin waktu yang tersedia untuk kegiatan belajar-mengajar dihabiskan untuk melatih para siswa mengenal huruf Arab (Asyrofi, 2014:51,53). Bahasa Arab membutuhkan keterampilan pengembangan pikiran dalam berkomunikasi lisan maupun tulisan untuk memahami dan mendapatkan informasi pengetahuan. Adapun aspek dalam bahasa Arab yaitu: keterampilan mendengar (maharatul istima'), keterampilan membaca (maharatul kalam), keterampilan membaca (maharatul qira'ah) dan keterampilan menulis (maharatul kitabah) (Hermawan, 2011:135).

Salah satu keterampilan yang ingin dicapai dan sangat dibutuhkan dari pembelajaran bahasa Arab adalah keterampilan membaca yang sering dikenal dengan sebutan (maharah al-qiraah). Namun, untuk mempelajari dan memahami bahasa Arab tidaklah mudah, perlu sebuah alat atau sistem untuk mempermudah mempelajari dan memahaminya.

Membaca dapat diklasifikasikan ke dalam tiga kelompok besar. Pertama, pengertian membaca yang ditarik dari interpretasi pengalaman membaca itu bermula dari penemuan dan berawal dengan pengelolaan tanda-tanda berbagai benda (membaca itu berawal dari tanda dan bertanda). Kedua, pengertian membaca yang ditarik dari interpretasi lambang grafis; membaca merupakan upaya pemerolehan makna dari untaian huruf tertentu. Ketiga, pengertian membaca yang ditarik dari keduanya, yakni membaca merupakan perpaduan dari pengalaman dan upaya memahami lambang-lambang grafis atau halaman bercetakan (Ahmad, 2017: 77)

Membaca hakikatnya adalah sesuatu yang rumit dan melibatkan banyak hal, tidak hanya melafalkan banyak tulisan yang Nampak, namun juga melibatkan aktivitas visual, berpikir, psikolinguistik, dan metakognitif. Sebagai proses visual membaca merupakan proses menerjemahkan simbol (berupa huruf) ke dalam bahasa lisan. Sebagai suatu proses berpikir, membaca mencakup aktivitas pengenalan kata, pemahaman literasi, interpretasi, membaca kritis, dan pemahaman kreatif. Pengenalan kata dapat berupa 
aktivitas membaca kata-kata dengan menggunakan kamus.

Sedangkan dalam pengajaran bahasa Arab salah satu yang harus diperhatikan adalah metode, karena keberhasialan suatu pengajaran bahasa sering kali dinilai dari metode yang digunakan, sebab metode dapat menentukan isi dan cara mengajarkan bahasa. Metode pembelajaran bahasa Arab mencakup cara kerja yang sitematis, efektif dan efisien untuk menyajikan materi bahan ajar (Abdurochman, 2016:43).

Metode al-Qiraah (reading method) yaitu sebuah metode yang dilakukan dengan menyajikan materi pelajaran dengan cara lebih mengutamakan membaca, yakni guru mula-mula membacakan topik-topik bacaan, kemudian diikuti oleh siswa (Zulkifli, 2011:87).

Metode al-Qiraah diajarkan bagi sekolah-sekolah yang bertujuan mengajarkan dan melatih keterampilan membaca dalam bahasa asing, yang diharapkan pembelajaran bahasa Arab dapat mencapai target dan dapat direalisasikan dalam waktu yang tersedia. Tujuan dari metode ini adalah agar siswa mahir membaca teks-teks yang berbahasa Arab secara baik (Syaiful Mustofa, 2011:173).

Dari permasalahan di atas, terdapat solusi yang dapat membantu siswa ataupun santri dalam menguasai maharah al-qiraah, yaitu menggunakan metode al-Qiraah alJahriyyah. Sebab dalam metode ini dapat dideteksi secara langsung yang salah dan benar atau yang ragu-ragu ketika membaca teks bahasa Arab karena metode belajar berlangsung secara tatap muka. Membaca Nyaring (al-Qiraah al-Jahriyyah) adalah membaca dengan melafalkan atau menyuarakan simbol-simbol tertulis berupa kata-kata atau kalimat yang dibaca.

Hal inilah yang menarik perhatian peneliti untuk menganalisis penerapan metode al-Qiraah al-Jahriyyah, sebab metode al-Qiraah al-Jahriyyah dapat dijadikan alat untuk mempermudah dalam menguasai Maharah al-Qiraah bagi siswa.

\section{METODE PENELITIAN}

Penelitan ini merupakan penelitian kualitatif, yaitu sebuah penelitian dengan pendekatan investigasi. Penelitian ini mengkaji perspektif partisipan dengan menggunakan strategi-strategi yang bersifat fleksibel dan interaktif. Dengan kata lain penelitian ini ditujukan untuk memahami fenomena sosial dari sudut pandang partisipan.

Subjek pada penelitian ini adalah siswa kelas X SMAIT Insantama Bogor Jawa Barat dengan jumlah 31 siswa. Adapun data dikumpulkan dengan melalui observasi, 
wawancara dan domentasi, serta data tersebut dianalisis dengan teknis triangulasi data. Yaitu dengan mendisplay, mereduksi, mengelompokkan dan memverifikasi data hasil penerapan metode al-Qiraah al-Jahriyyah

\section{HASIL DAN PEMBAHASAN}

Keterampilan membaca teks berbahasa Arab siswa dengan menggunakan metode al-Qiraah al-Jahriyyah di SMAIT Insantama Bogor dengan mengacu kepada hasil pengamatan yang telah peneliti lakukan mendapatkan hasil bahwa terdapat peningkatan keterampilan membaca teks berbahasa Arab siswa pada mata pelajaran Bahasa Arab dengan metode tersebut.

Hal ini dibuktikan dengan meningkatnya keterampilan membaca siswa dengan menggunakan metode al-Qiraah al-Jahriyyah. Adapun hasil peningkatan keterampilan membaca teks berbahasa Arab siswa dapat dilihat dari tabel di bawah ini :

Tabel 1

Rekapitulasi Hasil Uji Tes

\begin{tabular}{|c|c|c|c|c|}
\hline & Siklus 1 & Siklus 2 & Siklus 3 & Peningkatan Siklus \\
\hline Tes Lisan & 75.80 & 85.61 & 97.03 & 11.42 \\
\hline Tes Tulis & 74.70 & 82.25 & 88.06 & 5.81 \\
\hline Nilai Rata-rata & 75.25 & 84.38 & 92.29 & - \\
\hline
\end{tabular}

Berdasarkan analisis tabel di atas, dapat diketahui bahwa telah terjadi peningkatan pada setiap siklusnya. Hal ini dibuktikan dari hasil nilai rata-rata siswa sebelum guru tersebut melaksanakan penelitian tindakan kelas dengan dengan menerapkan metode alQiraah al-Jahriyyah dan setelahnya.

Pada nilai proses yang dilakukan oleh guru Bahasa Arab di SMAIT Insantama Bogor yaitu Bapak Eko Cahyo Susilo, S.Pd. dan Ibu Rizka Dara Afifah, S.Pd. nilai ratarata pembelajaran bahasa Arab yang terdapat di dalamnya hasil uji lisan dan tulis yaitu 75.25 dengan katagori siswa mendapat nilai cukup sesuai KKM pada sekolah tersebut. Adapun pada siklus ke-2 mengalami peningkatan sebesar 9.13 menjadi 84.38 dengan katagori nilai yang baik, dan pada siklus ke-3 terjadi peningkatan sebesar 7.91 menjadi 92.29 dengan katagori baik sekali. 
Tabel 2

Signifikansi Persiklus

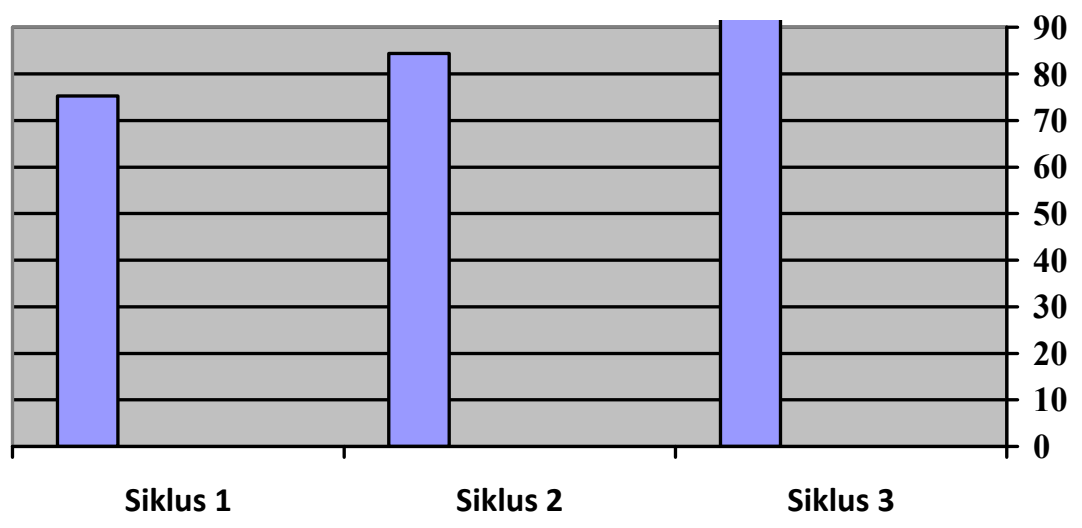

Adanya peningkatan pada setiap siklus itu terjadi karena beberapa faktor yaitu pada saat sebelum dilakukan penelitian guru telah mewawancarai beberapa siswa mengenai pembelajaran Bahasa Arab serta keterkaitan pembelajaran tersebut dengan penerapan Bahasa Arab sehari-hari sebagai praktiknya di kelas maupun di asrama.

Peningkatan pada setiap siklusnya cukup signifikan, apabila dilihat dari siklus ke1 (75.25) menjadi 84.38 pada siklus ke-2. Hal ini dikarenakan adanya perbaikan terutama bagi siswa yang masih mengobrol di dalam kelas, siswa yang kurang aktif, dan siswa yang masih kesulitan dalam membaca tulisan berbahasa Arab.

Kemudian pada siklus ke-2 terjadi peningkatan yaitu 84.38 menjadi 92.29. Hal ini dapat terjadi dikarenakan karena guru telah berusaha melakukan beberapa perbaikan untuk perencaan sebelum melanjutkan pada siklus ke-3. Walaupun dalam hal ini nilai rata-rata siswa ketika siklus ke-1 sudah mendapat katagori nilai yang cukup, namun setelah guru melakukan observasi langsung dan memperhatikan kebiasaan dan cara belajar siswa di dalam kelas guru dapat menganalisis dan menyimpulkan bahwa nilai kemampuan kognitif tersebut dapat lebih ditingkatkan lagi agar semua siswa mendapatkan katagori baik sekali dalam pembelajaran Bahasa Arab ini.

Pada proses pelakasanaan penelitian tindakan kelas guru mendapati beberapa siswa yang ketika di kelas belum mengalami peningkatan yang signifikan. Hal ini dikarenakan kondisi kesehatan dan daya kefokusan serta perhatian siswa tersebut yang kurang baik. Pada sisi lain terdapat siswa yang aktif di dalam kelas namun tidak aktif ketika proses pembelajaran belangsung. Hal ini tentu sangat mempengaruhi beberapa siswa yang lain baik dari segi pemahaman materi maupun yang lainnya.

Inilah sistem pendidikan di sekolah pasti terdapat kelebihan dan kekurangan di 
dalamnya baik dari sekolah tersebut maupun dari siswa-siswinya sendiri. Adapun di SMAIT Insantama khususnya di kelas $\mathrm{X}$ ada beberapa kekurangan dalam pembelajaran di kelas terutama dalam pembelajaran Bahasa Arab baik dari segi penggunaan metode maupun yang lainnya.

Adapun dalam aspek Qiraah (membaca) secara langsung, setelah guru melakukan tes lisan ada beberapa siswa yang masih kesulitan dalam membaca teks berbahasa Arab tersebut dikarenakan tidak adanya pembiasaan baik di sekolah maupun di asrama. Sehingga ada beberapa siswa yang masih perlu dibimbing dalam membacanya. Padahal kemampuan mengenal huruf Arab dalam Qiraah ini merupakan modal awal untuk mempelajari Bahasa Arab lebih lanjut.

Dengan kondisi kemampuan siswa yang demikian, maka guru menilai perlu perhatian lebih khususnya guru bahasa Arab agar siswa-siswi memiliki dasar yang baik di awal pembelajaran pada tingkat SMA ini. Sehingga guru berusaha untuk menyiapkan desain pembelajaran yang menarik dan menyenangkan agar siswa-siswi lebih termotivasi dalam belajar bahasa Arab.

Adapun langkah awal yang guru lakukan dalam mempersiapkannya yaitu dengan memberikan motivasi di setiap awal pembelajaran dan kesimpulan pada setiap akhir pembelajaran, memahami karakter belajar siswa, mengamati suasana kelas, memperhatikan siswa-siswi baik dari segi pemahaman saat berlangsungnya proses pembelajaran di dalam maupun di luar kelas, menanyakan hal-hal yang belum dimengerti, serta membantu yang siswa masih kesulitan dalam memahami teks berbahasa Arab dikarenakan latar belakang pendidikan siswa sebelumnya, guru juga memberikan apresiasi berupa pujian dan berjanji memberikan penghargaan berupa hadiah kepada siswa yang memperoleh nilai tertinggi pada setiap tes yang dilakukan selama penelitian.

Dari hasil analisis hasil belajar siswa pada siklus ke-1 guru menemukan ada beberapa siswa yang kurang memperhatikan proses pembelajaran, akan tetapi pada siklus ke-2 beberapa siswa yang kurang memperhatian tersebut dapat diatasi dengan cara memberikan perhatian khusus dan sesekali memberikan ice breaking berbahasa Arab terhadap semua siswa, begitupun pada siklus ke-3.

Untuk aktivitas visual membaca dan mengamati pada siklus ke-1 teradapat beberapa siswa yang kesulitan dalam membaca teks berbahasa Arab sehingga masih memerlukan bimbingan secara khusus dari guru, namun pada siklus ke-2 ketika guru 
melakukan tes lisan Bahasa Arab siswa menjadi lebih meningkat dibuktikan dengan siswa sudah mulai lancar membaca teks berbahasa Arab tersebut dan hampir semuanya lancar walau ada beberapa yang masih ada salah pengucapan tanda bacanya. Adapun pada siklus ke-3 guru mendapati hanya beberapa siswa yang masih tidak lancar dalam membaca teks berbahasa Arab. Berikut adalah hasil persentase rata-rata hasil belajar siswa pada siklus 1,2 dan 3 .

Tabel 3

Persentase Peningkatan Hasil Belajar Siswa

\begin{tabular}{|c|c|l|l|l|}
\hline Siklus & Siklus 1 & Siklus 2 & Siklus 3 & Peningkatan \\
\hline Persentase & 75.25 & 84.38 & 92.29 & $9.37 \%$ \\
\hline
\end{tabular}

Berdasarkan tebel tersebut dapat diketahui pada siklus ke-1 rata-rata hasil belajar siswa adalah $75.25 \%$ dan pada sikus ke-2 nilai rata-rata siswa meningkat menjadi 84.38 \%, sedangkan pada siklus ke-3 92.29\% atau meningkat sebesar 9.37\%. Dari hasil observasi selama penelitian maka disimpulkan bahwa metode al-Qiraah al-Jahriyyah cocok untuk diterapkan pada pembelajaran Bahasa Arab di kelas X SMAIT Insantama Bogor, karena dengan menggunakan metode tersebut dapat meningkatkan keterampilan membaca teks berbahasa Arab siswa kelas X.

Hal ini dibuktikan dengan beberapa strategi yang telah dilakukan dalam proses pembelajaran yang berlangsung selama penelitian yaitu : guru tidak menuntut bacaan siswa harus lancar dan baik namun guru lebih memahami terlebih dahulu gaya belajar lalu membimbing dan mengarahkan agar siswa dapat membaca dengan baik, guru juga memberikan waktu bagi siswa untuk latihan terlebih dahulu dengan saling menyimak antar teman sebangku atau yang lainnya, kemudian untuk menambah pemahaman siswa agar dapat lebih mudah dalam membaca secara baik sesuai indikator keberhasilan membaca. maka siswa tidak hanya membaca namun juga diberikan pemahaman sedikit demi sedikit arti dari teks tersebut.

\section{KESIMPULAN}


Berdasarkan analisis deskriptif yang dilaksanakan di SMAIT Insantama, maka peneliti menyimpulkan bahwa penerapan metode al-Qiraah al-Jahriyyah yang dilaksanakan oleh guru sekolah dapat meningkatkan keterampilan membaca teks berbahasa Arab siswa dengan persentase peningkatan 9,37\% atau 75,25 pada siklus ke-1, 84,38 pada siklus ke-2 dan 92,29 pada siklus ke-3. Dengan demikian maka peneliti menyarankan agar guru bahasa Arab dapat menggunakan metode al-Qiraah al-Jahriyyah sebagai salah satu alternatif model pembelajaran yang dapat diterapkan di sekolah, khususnya dalam meningkatkan keterampilan membaca siswa

\section{DAFTAR PUSTAKA}

Abdurrochman. 2016. Metode, Teknik, Evaluasi Pembelajaran Bahasa Arab. Lampung Timur : STIT Darul Fattah.

Ahmad, Arifin, 2017, Penerapan Permainan Bahasa (Katarsis) Untuk Meningkatkan Keterampilan Membaca Siswa Kelas IV A SD Negeri 01 Metro Pusat. Edu Humaniora, Jurnal Pendidikan Dasar

Arikunto, Suharsimi.2012. Dasar-Dasar Evaluasi Pendidikan.Jakarta : Bumi Aksara.

Asyrofi, Syamsuddin. 2016. Metodologi Pengajaran Bahasa Arab.Yogyakarta :Ombak.

Asyrofi. 2014. Model, Strategi, Permainan Efektif dalam Pengajaran Bahasa Arab. Yogyakarta : Aura Pustaka.

Bogdan dan Taylor. 1996. dikutip tidak langsung oleh Lexy J. Moeloeng, Metodologi Penelitian Kualitatif, PT. Remaja Rosda Karya Cet ke 27, Bandung

Hermawan, Acep. 2011. Metodologi Pembelajaran Bahasa Arab.Yogyakarta: Rosda

Musthofa, Syaiful. 2011. Stategi Pembelajaran Bahasa Arab. Malang : UIN Maliki Press.

Rosyidi, Abdul Wahab dan Ni'mah, Ma'lumatul. 2005. Memahami Dasar Pembelajaran Bahasa Arab. Malang : UIN Maliki.

Sugiyono. 2013. Metode Penelitian kualitatif, kuantitatif dan $R \& D$. Bandung Indonesia Penerbit Alfabeta.

Zulkifli. 2011. Metodologi Pengajaran Bahasa Arab Konvensional dan Kontemporer. Pecan baru:Zanafa Publishing 